\title{
PENGARUH BODY MASS INDEX DENGAN PREVALENSI DAN DERAJAT GEJALA PMS PADA MAHASISWI AKADEMI KEPERAWATAN DHARMA WACANA METRO
}

\author{
Nia Risa Dewi \\ Akademi keperawatan Dharma Wacana Metro \\ Jl.Kenanga no.3 16.c Mulyojati Kota Metro Lampung \\ e-mail: nia_risa@yahoo.co.id,
}

\begin{abstract}
Abstrak
Pre Menstrual syndrome (PMS) merupakan sekumpulan gejala yang di mulai satu minggu sampai beberapa hari sebelum datangnya haid, dan menghilang sesudah haid datang. Jenis penelitian deskrptif dengan rancangan penelitian Cross Sectional, bertujuan mengetahui prevalensi dan pengaruh antara Body Mass Index (BMI) dengan prevalensi PMS dan derajat gejala PMS pada mahasiswi Akper Dharma Wacana Metro. Populasi dalam penelitian ini adalah seluruh mahasiswi Akper Dharma Wacana Metro tingkat I, II dan III Tahun ajaran 2013/ 2014. Sampel penelitian sebanyak 82 responden. Hasil analisis diperoleh sebagian besar responden (89 \%) menderita PMS. Analisis derajat gejala PMS terhadap 73 responden yang mengalami PMS diperoleh 80,8\% mengalami gejala PMS ringan, 19,2\% mengalami gejala PMS sedang dan 0\% mengalami gejala PMS berat. Sebanyak 56,1\% responden dengan berat badan normal. 34,1\% dengan berat badan kurang dan hanya sebagian kecil $(9,8 \%)$ dengan berat badan berlebih. Uji chi square diperoleh kesimpulan tidak ada perbedaan proporsi kejadian PMS antara mahasiswi yang mempunyai berat badan kurang, berat badan normal dan berat badan berlebih ( $p$ value $=0,067$ ). Artinya tidak ada pengaruh BMI dengan prevalensi PMS. Selain itu, tidak ada perbedaan proporsi derajat gejala PMS antara mahasiswi yang mempunyai berat badan kurang, berat badan normal dan berat badan berlebih $\quad(p$ value $=0,079)$. Artinya tidak ada pengaruh BMI dengan derajat gejala PMS. Kejadian PMS dapat dicegah dan diminimalisir dengan cara modifikasi pola hidup dengan cara komunikasi masalah PMS dengan orang terdekat, dengan penurunan asupan garam dan karbohidrat, penurunan konsumsi kafein dan olahraga secara teratur.
\end{abstract}

Kata Kunci: Body Mass Index, Pre Menstrual Syndrome 


\section{Pendahuluan}

Menstruasi merupakan salah satu masa yang pasti dilalui dalam siklus kehidupan seorang wanita normal. Pada masa ini wanita sering mengeluh berbagai gangguan menstruasi baik premenstruasi maupun disaat menstruasi. Beberapa masalah menstruasi yaitu Pre Menstrual syndrome (PMS), dysmenore, menstruasi yang tidak teratur, amenore dan darah mentruasi yang terlalu banyak.

\section{Pre Menstrual syndrome (PMS)} merupakan keluhan-keluhan yang biasanya mulai satu minggu sampai beberapa hari sebelum datangnya haid, dan menghilang sesudah haid datang, walaupun kadang-kadang berlangsung terus sampai haid berhenti. Keluhankeluhan terdiri atas gangguan emosional berupa iritabilitas, gelisah, insomnia, nyeri kepala, perut kembung, mual, pembesaran dan rasa nyeri pada payudara, dan sebagainya, sedang pada kasus-kasus yang berat terdapat depresi, rasa ketakutan, gangguan konsentrasi, dan peningkatan gejala-gejala fisik tersebut diatas ${ }^{1 .}$

Beberapa faktor yang dapat meningkatkan risiko terjadinya PMS, antara lain, riwayat keluarga, status perkawinan, usia, stress, diet, kurangnya aktivitas olahraga, merokok, minum alcohol dan Body Mass Indeks (BMI) (Saryono dan Waluyo, 2009). Faktor-faktor risiko tersebut dapat memperburuk gejala dan keluhan premenstrual syndrome bila tidak ditangani dengan baik ${ }^{2}$

Penelitian. Deuster, Adera, dan Paul tahun 1999 di Wilayah Virginia yang berjudul "Biological, Social, and Behavioral Factors Associated With Premenstrual Syndrome" terhadap 874 wanita didapatkan $8.3 \%$ (95\% CI, 6.4\%-10.2\%) menderita PMS. Wanita yang mengalami stress mempunyai peluang 3,7 kali untuk mengalami PMS. Konsumsi alcohol mempunyai peluang 2,5 kali untuk mengalami PMS dan wanita yang melakukan latihan fisik yang aktif cenderung 2,9 kali mengalami PMS dibanding wanita yang tidak mengalami PMS. Wanita muda, berkulit hitam dan mempunyai riwayat menstruasi yang lama lebih sering mengalami PMS ${ }^{3}$.

Penelitian lain oleh Potter, Bouyer, Trussell dan Moreau tahun 2009 yang berjudul "Premenstrual Syndrome Prevalence and Fluctuation over Time: Results from a French Population-Based Survey" menyebutkan bahwa dari 2863 wanita Prancis pada tahun 2003 -2004, sebanyak $4,1 \%$ mengalami PMS yang berat (6 gejala), 8,1\% PMS sedang (lima gejala) dan $12,2 \%$ wanita yang mengalami PMS merasa terganggu aktifitas sehari hari. Faktor resiko antara lain hormonal, psikologis dan fisik dengan stressor kehidupan dan konsumsi hormonal eksogen ${ }^{4}$.

Pada tahun 2012, Dewi dengan penelitian yang berjudul Prevalensi, derajat gejala, tipe dan faktor resiko Pre Menstrual Syndrome terhadap 274 responden pada wanita usia reproduksi di lingkungan Universitas Sriwijaya didapatkan hasil 92,7\% \% responden mengalami PMS. $7,3 \%$ responden mengalami derajat gejala ringan, $60,9 \%$ responden gejala sedang, $24,5 \%$ responden mengalami gejala berat. $84,7 \%$ responden mengalami PMS tipe kombinasi dari beberapa tipe, 5,8\% responden mengalami PMS tipe $\mathrm{C}, 1,8 \%$ responden mengalami tipe $\mathrm{A}, 0,4 \%$ responden mengalami tipe $\mathrm{H}$ dan $0 \%$ mengalami tipe D. Status perkawinan (nilai $\mathrm{p}=0,037$ ), Usia (nilai $\mathrm{p}=0,035$ ), stress (nilai p 0,000), diet atau kebiasaan makan dan minum (nilai $p$ 0,007) dan kegiatan fisik seperti olahraga (nilai $\mathrm{p}$ 0,000), memiliki hubungan yang signifikan dengan kejadian PMS. Pada penelitian tersebut belum diteliti faktor 
resiko PMS yaitu Body Mass Indeks $(\mathrm{BMI})^{5}$

Penelitian Supriyono, Bambang (2003) tentang Hubungan Indeks Massa Tubuh dengan Sindrom Prahaid. Thesis, Universitas Diponegoro terhadap 253 orang mahasiswi usia antara 18 sampai 26 tahun, didapatkan hasil bahwa IMT berat badan berlebih mempunyai risiko 43,432 kali terjadi sindroma prahaid $\mathrm{p}<0,001$, sedangkan berat badan kurang cenderung mempunyai proteksi terhadap kejadian sindroma prahaid $(\mathrm{p}=0,853)^{5}$.

Keperawatan sebagai bentuk pelayanan kepada manusia baik sehat maupun sakit yang meliputi bio-psiko-sosial dan spiritual di butuhkan dalam setiap siklus kehidupan. Walaupun PMS masih dikategorikan keadaan fisiologis, namun bila tidak disadari dan tidak di minimalisir, hal tersebut dapat mengganggu aktifitas dan kondisi psikologis seorang wanita. Hasil studi pendahuluan terhadap 10 orang mahasiswi di Akademi Keperawatan Dharma Wacana Metro dengan proporsi tubuh yang beragam (kurus, sedang dan gemuk), didapatkan bahwa seluruhnya pernah mempunyai keluhan sebelum menstruasi diantaranya adalah tidak mood, pegal pegal, payudara terasa mengencang, emosi labil, pusing, ingin tidur terus, malas beraktifitas, susah tidur, mual, nafsu makan meningkat dan mudah menangis.

\section{Studi Literatur}

1. Pengertian Premenstrual Syndrome

Premenstrual syndrome (PMS) merupakan keluhan-keluhan yang biasanya mulai satu minggu sampai beberapa hari sebelum datangnya haid, dan menghilang sesudah haid datang, walaupun kadang-kadang berlangsung terus sampai haid berhenti ${ }^{1}$

2. Penyebab Premenstrual Syndrome

Penyebab pasti PMS tidak diketahui, terdapat beberapa penyebab PMS yaitu sebagai berikut : Faktor Hormonal, faktor kimiawi, faktor genetik, faktor psikologis, faktor gaya hidup, defisiensi endorphin ${ }^{7)}$

3. Gejala Premenstrual Syndrome (PMS) 8

Tabel 1. Gejala-gejala premenstrual syndrome (PMS)

\begin{tabular}{|c|c|}
\hline Gejala Fisik & Gejala Emosional \\
\hline 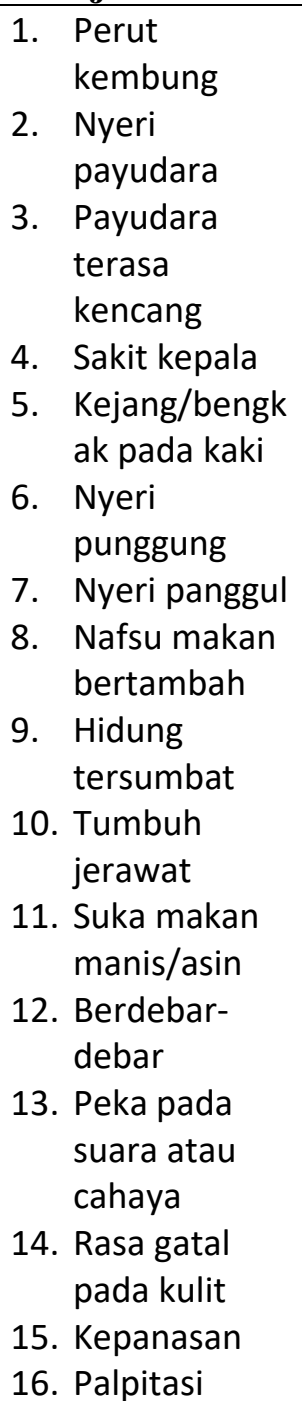 & $\begin{array}{l}\text { 17. Cemas } \\
\text { 18. Suka } \\
\text { menangis/merasa } \\
\text { ingin menangis } \\
\text { 19. Agresif/memberon } \\
\text { tak } \\
\text { 20. Pelupa } \\
\text { 21. Tidak bisa tidur } \\
\text { 22. Merasa tegang } \\
\text { 23. Sensitif } \\
\text { 24. Rasa bermusuhan } \\
\text { 25. Suka } \\
\text { marah/merasa } \\
\text { ingin marah } \\
\text { 26. Ketakutan tanpa } \\
\text { sebab yang jelas } \\
\text { 27. Perubahan } \\
\text { dorongan seksual } \\
\text { 28. Konsentrasi } \\
\text { berkurang } \\
\text { 29. Merasa tidak } \\
\text { nyaman } \\
\text { 30. Pikiran bunuh diri } \\
\text { 31. Keinginan } \\
\text { menyendiri } \\
\text { 32. Perasaan bersalah } \\
\text { 33. Kelemahan }\end{array}$ \\
\hline
\end{tabular}

4. Faktor Risiko Premenstrual Syndrome (PMS)

Faktor Risiko Premenstrual Syndrome (PMS) yaitu riwayat keluarga, diet, status perkawinan usia, stres (faktor stres memperberat gangguan PMS), kebiasaan merokok dan minum alkohol 
dapat memperberat gejala PMS, Body Mass Indeks (BMI). ${ }^{8)}$

\section{Metode Penelitian}

Jenis penelitian Deskrtiptif dengan rancangan penelitian Cross Sectional. Populasi dalam penelitian ini adalah seluruh mahasiswi Akper Dharma Wacana Metro tingkat I, II dan III Tahun ajaran 2013/ 2014. Sampel penelitian sebanyak 82 responden.

Alat Pengumpulan Data berupa kuesioner gejala premenstruasi yang dimodifikasi dari Rayburn (2001) yang terdiri dari 20 daftar pertanyaan dan timbangan dan meteran tinggi badan untuk mengukur berat badan dan tinggi badan. Peneliti dan tenaga pencacah yang merupakan mahasiswa Akper Dharma Wacana melakukan koordinasi tentang penelitian yang akan dilakukan kemudian menjelaskan cara pengisian kuesioner dan memberikan kuesioner pada calon responden serta memberikan kesempatan untuk bertanya. Kuesioner dapat diisi dalam rentang waktu 7-10 hari sebelum menstruasi atau hingga menstruasi selesai. Setelah di isi, kuesioner dikumpulkan kembali dan diperiksa kelengkapannya.

Analisis data yang dilakukan yaitu secara univariat dan bivariat. Analisa bivariat dengan menggunakan uji chi square. Analisis bivariat menggunakan program SPSS versi 16.0

\section{Hasil penelitian}

Tabel 1.

Distribusi Frekuensi

Prevalensi, Derajat Gejala PMS dan Body Mass Index

Mahasiswi Akper Dharma Wacana Metro T.A 2013/ 2014

\begin{tabular}{|c|l|c|c|}
\hline No & \multicolumn{1}{|c|}{ Variabel } & $\begin{array}{c}\text { Frekuensi } \\
(\mathrm{N})\end{array}$ & $\begin{array}{c}\text { Prosentase } \\
(\%)\end{array}$ \\
\hline 1 & Pre Menstrual Syndrome & & \\
& 1. Tidak PMS & 9 & 11 \\
& 2. PMS & 73 & 89 \\
\hline
\end{tabular}

\begin{tabular}{|c|c|c|c|}
\hline 2 & $\begin{array}{l}\text { Derajat Gejala PMS } \\
\text { 1. Gejala Ringan } \\
\text { 2. Gejala Sedang } \\
\text { 3. } \quad \text { Gejala Berat }\end{array}$ & $\begin{array}{c}59 \\
14 \\
0\end{array}$ & $\begin{array}{c}80.8 \\
19,2 \\
0\end{array}$ \\
\hline 3 & $\begin{array}{l}\text { Body Mass Index } \\
\text { 1. Berat badan kurang } \\
\text { 2. } \quad \text { Berat badan normal } \\
\text { 3. } \quad \text { Berat badan berlebih }\end{array}$ & $\begin{array}{c}28 \\
46 \\
8\end{array}$ & $\begin{array}{c}34,1 \\
56,1 \\
9,8\end{array}$ \\
\hline
\end{tabular}

Tabel 2.

Distribusi responden menurut Body Mass Index dan Prevalensi PMS

\begin{tabular}{|c|c|c|c|c|c|c|c|}
\hline \multirow{3}{*}{$\begin{array}{l}\text { Body } \\
\text { Masss } \\
\text { Index } \\
\text { (BMI) } \\
\end{array}$} & \multicolumn{4}{|c|}{$\begin{array}{c}\text { Pre Menstrual } \\
\text { Syndrome (PMS) }\end{array}$} & \multirow{2}{*}{\multicolumn{2}{|c|}{ Total }} & \multirow{3}{*}{$\begin{array}{c}P \\
\text { value }\end{array}$} \\
\hline & \multicolumn{2}{|c|}{$\begin{array}{l}\text { Tidak } \\
\text { PMS } \\
\end{array}$} & \multicolumn{2}{|c|}{ PMS } & & & \\
\hline & $\mathbf{N}$ & $\%$ & $\mathbf{N}$ & $\%$ & $\mathbf{N}$ & $\%$ & \\
\hline $\begin{array}{l}\text { Berat } \\
\text { badan } \\
\text { kurang }\end{array}$ & 0 & 0 & 28 & 100 & 28 & 100 & 0,067 \\
\hline $\begin{array}{c}\text { Berat } \\
\text { badan } \\
\text { normal }\end{array}$ & 8 & 17,4 & 38 & 82,6 & 46 & 100 & \\
\hline $\begin{array}{c}\text { Berat } \\
\text { badan } \\
\text { berlebih }\end{array}$ & 1 & 12,5 & 7 & 87,5 & 8 & 100 & \\
\hline Jumlah & 9 & 11,0 & 73 & 89,0 & 82 & 100 & \\
\hline
\end{tabular}

Tabel 3.

Distribusi responden menurut Body Mass Index dan Derajat Gejala PMS

\begin{tabular}{|c|c|c|c|c|c|c|c|}
\hline \multirow[t]{3}{*}{$\begin{array}{c}\text { Body Masss } \\
\text { Index }\end{array}$} & \multicolumn{4}{|c|}{$\begin{array}{c}\text { Derajat Gejala } \\
\text { Pre Menstrual } \\
\text { Syndrome }\end{array}$} & \multirow{2}{*}{\multicolumn{2}{|c|}{ Total }} & \multirow{3}{*}{$\begin{array}{c}P \\
\text { val } \\
\text { ue }\end{array}$} \\
\hline & \multicolumn{2}{|c|}{$\begin{array}{c}\text { Gejala } \\
\text { Ringan }\end{array}$} & \multicolumn{2}{|c|}{$\begin{array}{c}\text { Gejala } \\
\text { Sedang }\end{array}$} & & & \\
\hline & $\mathbf{N}$ & $\%$ & $\mathbf{N}$ & $\%$ & $\mathbf{N}$ & $\%$ & \\
\hline $\begin{array}{l}\text { Berat badan } \\
\text { kurang }\end{array}$ & 26 & 92,9 & 2 & 7,1 & 28 & 100 & 0,07 \\
\hline $\begin{array}{c}\text { Berat badan } \\
\text { normal }\end{array}$ & 27 & 71,1 & 11 & 28,9 & 38 & 100 & \\
\hline $\begin{array}{c}\text { Berat badan } \\
\text { berlebih }\end{array}$ & 6 & 85,7 & 1 & 14,3 & 7 & 100 & \\
\hline Jumlah & 59 & 80,8 & 14 & 19,2 & 73 & 100 & \\
\hline
\end{tabular}




\section{Pembahasan}

Hasil analisis korelasi antara BMI dengan prevalensi PMS diperoleh bahwa ada sebanyak 28 dari 28 (100\%) mahasiswi yang mempunyai berat badan kurang mengalami PMS. Mahasiswi yang mempunyai berat badan normal ada 38 dari $46 \quad(82,6 \%)$ mengalami PMS. Sedangkan mahasiswi yang berat badannya berlebih ada 7 dari $8(87,5 \%)$ mengalami PMS. Hasil uji statistic diperoleh nilai $\mathrm{p}=0,067$ maka dapat disimpulkan tidak ada perbedaan proporsi kejadian PMS antara mahasiswi yang mempunyai berat badan kurang, berat badan normal dan berat badan berlebih.

Berdasarkan penelitian yang dilakukan di Prancis pada 1.034 wanita didapatkan nilai $\mathrm{BMI}>30$ secara signifikan mempengaruhi PMS 4 .

Perempuan dengan berat badan yang berlebihan, 4-5 kali lebih sering terjadi gangguan fungsi ovarium. Perempuan yang gemuk menunjukkan aktivitas kelenjar suprarenal yang berlebihan, peningkatan produksi testosterone androstenadion serta peningkatan rasio estron atau esradiol 2,5. Selain itu ditemukan pula penurunan kadar sex hormone binding globuline (SHBG) serum

Penelitian $^{6}$ Hubungan Indeks Massa Tubuh dengan Sindrom Prahaid menyimpulkan bahwa BMI kelompok berat badan berlebih mempunyai risiko terjadinya PMS, dan semakin tinggi BMI semakin berat derajat PMS.

Hasil analisis korelasi antara BMI dengan derajat gejala PMS diperoleh bahwa ada sebanyak 26 dari $28(92,6 \%)$ mahasiswi yang mempunyai berat badan kurang mengalami gejala PMS ringan. Mahasiswi yang mempunyai berat badan normal ada 27 dari $38(71,1 \%)$ mengalami gejala PMS ringan. Sedangkan mahasiswi yang berat badannya berlebih ada 6 dari 8 $(85,7 \%)$ mengalami gejala PMS ringan. Hasil uji statistic diperoleh $\mathrm{P}$ value $=$
0,079 berarti tidak ada perbedaan proporsi derajat gejala PMS antara mahasiswi yang mempunyai berat badan kurang, berat badan normal dan berat badan berlebih. Hasil penelitian ini tidak sesuai dengan penelitian ${ }^{4}$ bahwa $4,1 \%$ wanita mengalami gejala PMS parah, dan 8,1\% wanita mengalami gejala PMS sedang.

Menurut peneliti, dengan berat badan normal responden memungkinkan gejala PMS yang terjadi tidak berat.

\section{Kesimpulan}

1. Hasil analisis terhadap 82 responden diperoleh sebagian besar mahasiswi Akper Dharma Wacana Metro yaitu $89 \%$ menderita PMS.

2. Hasil analisis derajat gejala PMS terhadap 73 responden yang mengalami PMS diperoleh sebagian besar $(80,8 \%)$ mengalami gejala PMS ringan, 19,2\% mengalami gejala PMS sedang dan tidak ada reponden $(0 \%)$ mengalami gejala PMS berat.

3. Hasil analisis terhadap 82 responden diperoleh sebagian besar mahasiswi Akper Dharma Wacana Metro yaitu $56,1 \%$ mempunyai berat badan normal. $34,1 \%$ mempunyai berat badan kurang dan hanya sebagian kecil $(9,8 \%)$ yang mempunyai berat badan berlebih

4. Tidak ada perbedaan proporsi kejadian PMS antara mahasiswi yang mempunyai berat badan kurang, berat badan normal dan berat badan berlebih. Hal ini dibuktikn dari hasil uji statistic diperoleh $p$ value $=0,067$. Artinya tidak ada pengaruh BMI dengan prevalensi PMS.

5. Tidak ada perbedaan proporsi derajat gejala PMS antara mahasiswi yang mempunyai berat badan kurang, berat badan normal dan berat badan berlebih. Hal ini dibuktikan dari hasil uji statistic diperoleh $p$ value $=0,079$. Artinya tidak ada pengaruh BMI dengan derajat gejala PMS. 


\section{Rekomendasi}

Kejadian PMS dapat dicegah dan diminimalisir dengan cara modifikasi pola hidup dengan cara komunikasi masalah PMS dengan orang terdekat, dengan penurunan asupan garam dan karbohidrat (nasi, kentang, roti) dapat mencegah edema (bengkak) pada beberapa wanita. Penurunan konsumsi kafein (kopi) juga dapat menurunkan ketegangan, kecemasan dan insomnia (sulit tidur).dan olahraga teratur. Selain itu baik untuk tetap menjaga berat badan normal untuk menghindari terjadinya gejala PMS yg lebih berat.

\section{Daftar Pustaka}

1. Wiknjosastro, H. 2005. Ilmu Kebidanan. Jakarta : Yayasan Bina Pustaka Sarwono Prawirohardjo

2. Health Media Nutrition Series. 1996. Women And Nutrition. Jakarta: Bumi Aksara

3. Deuster PA, Adera T, South-Paul J. 1999. Biological, social, and behavioral factors ssociated with premenstrual syndrome. Arch Fam Med. Mar-Apr;8(2):122-8. http://www.ncbi.nlm.nih.gov/pubmed/10 101982

4. Julia Potter, Jean Bouyer, James Trussell, and Caroline Moreau. Journal of Women's Health. January 2009, 18(1): 31-39. doi:10.1089/jwh.2008.0932.

5. Dewi., N. R. 2012. Prevalensi, derajat gejala, tipe dan faktor resiko Pre Menstrual Syndrome. http://eprints.unsri.ac.id/5158/

6. Supriyono, Bambang (2003) tentang Hubungan Indeks Massa Tubuh dengan Sindrom Prahaid. Thesis, Universitas Diponegoro.

http://eprints.undip.ac.id/12280/

7. Saryono dan Sejati. .2009. Sindrom Premenstruasi . Yogyakarta : Nuha Medika

8. Rayburn, W. 2001. Obstetri dan Ginekologi. Jakarta : Widya Medika 